\title{
ANALISA DAN PERANCANGAN WEB SITE SOCIAL-COMMERCE UMKM
}

\author{
Endang Supriyati \\ Fakultas Teknik, Program Studi Teknik Informatika \\ Universitas Muria Kudus \\ Email: endang.supriyati@umk.ac.id \\ Mohammad Iqbal \\ Fakultas Teknik, Program Studi Teknik Elektro \\ Universitas Muria Kudus \\ Email: mohammad.iqbal@umk.ac.id \\ Tutik Khotimah \\ Fakultas Teknik, Program Studi Teknik Informatika \\ Universitas Muria Kudus \\ Email: tutik.khotimah@umk.ac.id
}

\begin{abstract}
ABSTRAK
Pertumbuhan internet mengubah perilaku konsumen dalam mengambil keputusan. Pertukaran informasi melalui media sosial menjadi referensi penting bagi konsumen dalam mengambil keputusan pembelian. Transaksi bisnis secara online dan kesuksesan e-commerce tergantung pada ketepatan desain dari sebuah produk. Setiap situs social commerce, paling tidak mempunyai satu set minimal fitur desain social commerce. UMKM merupakan salah satu tiang ekonomi bangsa. Salah satu permasalahan pada UMKM adalah pemasaran produk. Untuk membangun UMKM yang lebih kuat dalam pemasaran maka perlu dibuat wweb site yang mampu memasarkan produk secara lebih luas. Dengan adanya social commerce, akan mampu memasarkan produk, merekomendasi produk dan menampilkan berbagai informasi produk-produk UMKM. Sebelum membangun sistem, didahului dengan perancangan sistem, perancangan ini menggunakan UML (Unified Modeling Language). Hasil penelitian ini berupa rancangan website social commerce untuk UMKM.
\end{abstract}

Kata kunci: social commerce, UMKM, UML.

\begin{abstract}
The growth of the Internet is changing the behavior of consumers in making decisions. Exchange of information through social media become an important reference for consumers in making purchasing decisions. Business transactions online and the success of e-commerce depends on the precision of the design of a product. Every social commerce site, has at least a minimum set of design features of social commerce. SMEs is one of the nation's economic pillars. One of the problems in SMEs is the marketing of products. To build a stronger SMEs in marketing needs to be created wweb site that is able to market the product more widely. With the social commerce, will be able to market the product, recommends the product and displays a variety of information products SMES. Before building the system, preceded by system design, this design using UML (Unified Modeling Language)
\end{abstract}

Keywords: Social Commerce, SMEs, UML.

\section{PENDAHULUAN}

Sosial commerce berasal dari kombinasi media sosial dan e-commerce. Pada sosial commerce, pengguna dapat melakukan transaksi bisnis atau sekedar browsing saja. Media sosial berisi individu dalam jumlah besar yang potensial dalam konten dan juga sumber informasi. Social Commerce terdiri dari toolset dan teknologi dimana customer bisa berpartisipasi membangun konten dan berbagi informasi produk dan layanan dari sebuah bisnis online [1]. Social commerce mempunyai dua komponen makro yaitu manajemen e-commerce dan manajemen relasi sosial. Management e-commerce terdiri dari katalog, keranjang belanja, diskon, customer, penjual, checkout, order, pengiriman dan manjemen pembayaran. Untuk manajemen relasi sosial komponennya terdiri dari daftar sosial, rekomendasi sistem, rating transaksi, review produk dan manajemen komunikasi [2]. Sosial commerce berbeda (tabel 1) dari e-commerrce di berbagai aspek, termasuk model bisnis, nilai kreasi, komunikasi customer dan koneksi, sistem interaksi, desain, dan platform [3]. 
Tabel 1. Perbedaan s-commerce dan e-commerce

\begin{tabular}{|c|c|c|}
\hline Aspek & e-commerce & Social commerce \\
\hline Model bisnis & - Traditional & $\begin{array}{l}\text { - Memerlukan model bisnis yang baru } \\
\text { yang bisa berjalan pada teknologi } \\
\text { sekarang (Web 2.0, cloud computing } \\
\text { dan SOA) } \\
\text { - Co-design } \\
\text { - Sosial dan customer oriented }\end{array}$ \\
\hline Nilai Kreasi & $\begin{array}{l}\text { Desain bisnis proses, produk atau } \\
\text { layanan terbatas pada } \\
\text { perusaahaan atau partners. }\end{array}$ & $\begin{array}{l}\text { - Partisipasi dan kolaborasi } \\
\text { - Menciptakan pendapatan(revenue) } \\
\text { berdasarkan keterbatasan perhatian } \\
\text { - Mencati peluang bisnis baru }\end{array}$ \\
\hline Rantai Nilai & Aktor yang terbatas & $\begin{array}{l}\text { - Banyak aktor dimana motivasi } \\
\text { partisipan dihargai }\end{array}$ \\
\hline $\begin{array}{l}\text { Koneksi } \\
\text { Customer/Komunikasi } \\
\text { /Percakapan }\end{array}$ & $\begin{array}{l}\text { - } \text { Customer berinteraksi } \\
\text { secara individu dengan } \\
\text { website e-commerce dan } \\
\text { tidak berhubungan dengan } \\
\text { customer lain } \\
\text { - Tidak ada komunikasi dari } \\
\text { customer ke perusahaan } \\
\text { atau dari customer ke } \\
\text { customer }\end{array}$ & $\begin{array}{l}\text { - Kolaborasi dan partisipasi } \\
\text { - melibatkan komunitas online yang } \\
\text { mendukung koneksi sosial untuk } \\
\text { meningkatkan percapakan antar } \\
\text { customer }\end{array}$ \\
\hline Sistem Interaksi & $\begin{array}{l}\text { - Browsing satu arah, dimana } \\
\text { informasi dari customer } \\
\text { jarang dikirim balik ke } \\
\text { perusahaan atau customer } \\
\text { lain } \\
\text { - Penciptaan konten yang } \\
\text { searah (dari perusahaan ke } \\
\text { customer) } \\
\text { - Informasi ke audience relatif } \\
\text { pasif }\end{array}$ & $\begin{array}{l}\text { - Mengembangkan kesosialan dan } \\
\text { pendekatan interaktif dimana } \\
\text { membiarkan customer lebih } \\
\text { ekspresif dan membagikan informasi } \\
\text { dengan customer lain dan juga ke } \\
\text { perusahaan. } \\
\text { - Menciptakan komunitas konten }\end{array}$ \\
\hline Design & 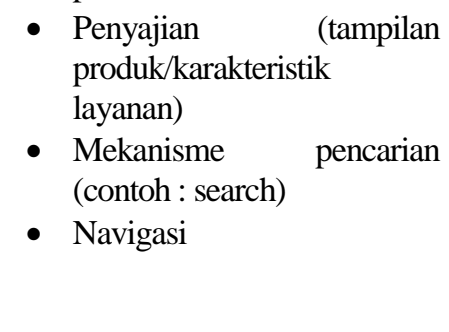 & $\begin{array}{l}\text { - Web } 2.0 \text { berdasar pada desain user } \\
\text { interaktif yang bisa melakukan } \\
\text { identifikasi, interaksi dan } \\
\text { komunikasi seperti : } \\
\circ \text { Aktor yang dikenali } \\
\circ \text { Percakapan diantara aktor } \\
\circ \text { Partisipasi aktor } \\
\circ \text { Tag/rank/rate/review/comment }\end{array}$ \\
\hline Platform & $\begin{array}{l}\text { - Web 1.0 (B2C), EDI or web } \\
\text { service (untuk B2B) }\end{array}$ & $\begin{array}{l}\text { - Web 2.0, Cloud Computing, SOA } \\
\text { - Kolaborasi }+ \text { Partisipasi } \\
\text { Keterbukaan }\end{array}$ \\
\hline Masalah Hukum & $\begin{array}{l}\text { - Menekankan } \\
\text { kebijakan }\end{array}$ & - Butuh penenkanan \\
\hline
\end{tabular}

Teknologi informasi diarahkan untuk mendukung proses bisnis utama dan pendukung yang ada di Usaha Mikro Dan Usaha Kecil Menengah (UMKM). korelasi Internet Marketing dengan PO5 cukup kuat $(-0,358)$ akan tetapi arahnya negatif sehingga semakin kecil pengaturan investasi TI semakin kecil juga penggunaan Internet Marketing[4].

\section{METODE PENELITIAN}

Langkah-langkah dalam penelitian ini terlihat pada gambar 1. 


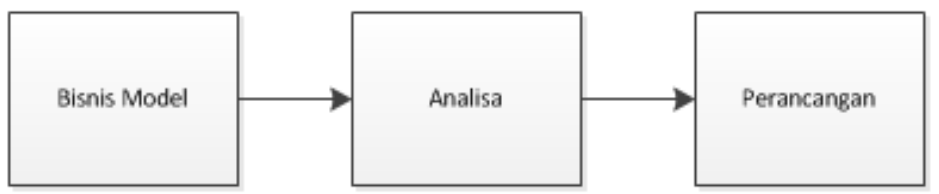

\section{Gambar 1. Metode Penelitian Social Commerce}

Gambar 1 menjelaskan langkah-langkah penelitian yang diawali dengan bisnis model, analisa kebutuhan pengguna dan konten manajemen website social commerce, kemudian perancangan untuk membangun website.

\section{HASIL DAN PEMBAHASAN}

\subsection{Bisnis Model}

Bisnis model menggambarkan desain atau arsitektur dari suatu mekanisme[5], seperti yang terlihat pada gambar 2 .

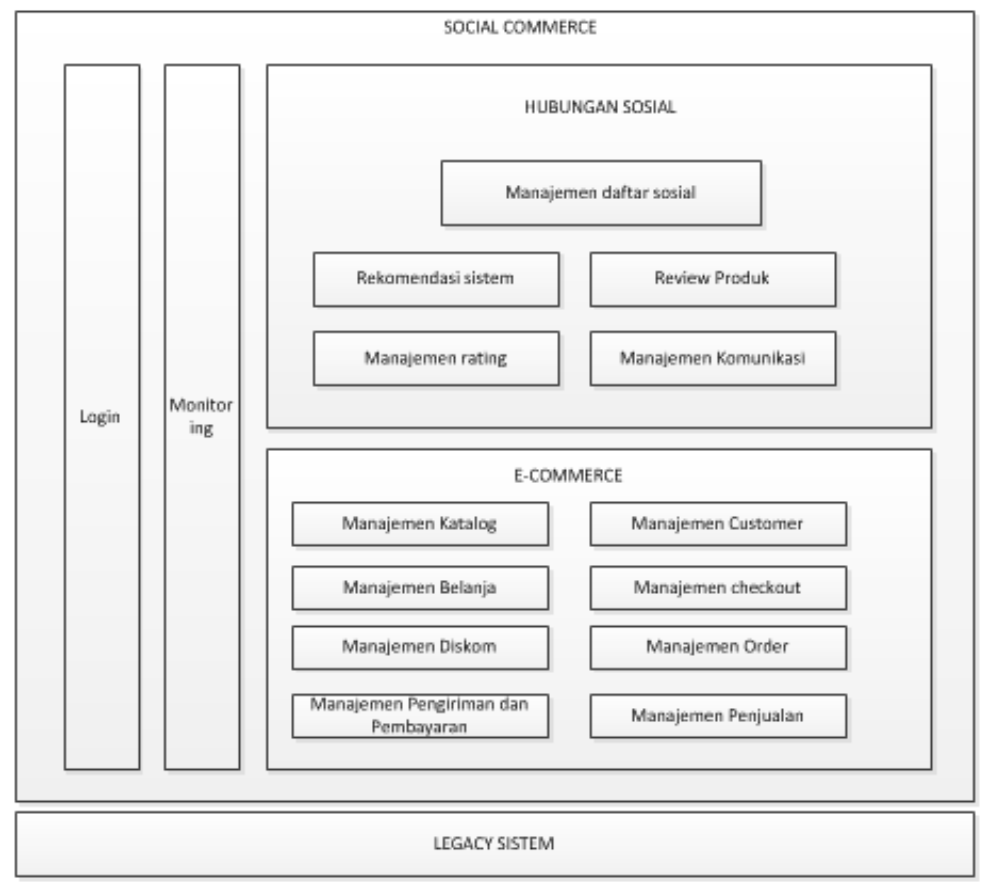

Gambar 2. Arsitektur Social Commerce [2]

Gambar 2 menjelaskan arsitektur social commerce, sebelah kiri ada blok login dan monitoring untuk relasi sosial dan e-commerce yang merupakan bagian dari sistem. Kemudian bagian relasi sosial yang memungkinkan komunikasi antara perusahaan dengan customer dan juga komunikasi antara customer dengan customer. Selanjutnya adalah bagian e-commerce yang memiliki beberapa komponen yang terkait dengan bisnis perusahaan. Bagian bawah adalah legacy system, legacy sistem ini berarti teknologi, sistem komputer bahkan aplikasi terdahulu yang digunakan oleh perusahaan yang mungkin sudah kadaluiarsa.

\subsection{Analisis}

Pada bagian ini akan dianalisa siapa saja pengguna dan komponen-komponen yang terlibat pada website social-commerce.

a. Pengguna

1) Visitor

Mereka memiliki akses ke pasar umum dan mereka dapat melihat dan membeli produk. Visitor tidak memerlukan otentifikasi/konfirmasi sebagai user. 
2) Shopper

Pembeli adalah pengguna yang mempunyai otentifikasi. Mereka dapat mengotentikasi dengan media sosial(facebook,twiter dll) atau menggunakan alamat email. Pembeli dapat memodifikasi preferensi untuk memiliki pengalaman yang lebih baik ketika mereka mencari produk. Mereka dapat melihat, membeli produk dan berlangganan berita berkala dari perusahaan.

3) Customer

Customer adalah pengguna yang memiliki sebuah toko. Pelanggan harus mendaftar dulu ke website e-commerce untuk bisa berjualan. Customer diperbolehkan mengakses dasboard, untuk mengatur keperluannya.

4) Administrator

Admin adalah pekerja yang paling tinggi levelnya, dia bisa akses kemana-mana.

b. Komponen e-commerce

1) Manajemen katalog

Manajemen katalog, yang berlaku untuk pelanggan dan penjual, untuk mengatur kegiatan yang berkaitan dengan produk dan kategori. Hal ini memungkinkan penjual untuk memasukkan dan memperbarui kategori baru dalam sistem dan berhubungan dengan fitur produk misalnya harga, judul dan deskripsi. Komponen ini juga mengelola stok produk, diskon dan rincian pemesanan.

2) Manajemen Pelanggan

Manajemen pelanggan memiliki untuk mengelola akun perdagangan, rekening, data pelanggan dan alamat pengiriman. Manajemen pelanggan terkait dengan checkout dan manajemen pesanan yang menyediakan alamat pelanggan dan rekening perusahaan.

3) Manajemen Penjualan

Manajemen Penjualan mengatur rekening penjualan dalam sistem penjualan.

4) Manajemen Keranjang Belanja

Manajemen keranjang belanja, memungkinkan pelanggan untuk menambahkan produk dalam keranjang, memperbarui kuantitas sudah memesan dan menghapus item dari keranjang pengguna..

5) Manajemen Checkout

Manajemen checkout mengatur semua pesanan pelanggan. Komponen ini terkait dengan komponen manajemen pelanggan, untuk mengambil informasi pelanggan, dan komponen keranjang belanja, untuk mengetahui apa produk yang dipesan oleh pelanggan.

6) Manajemen Order

Manajemen order memungkinkan penjual untuk mengatur pesanan yang sudah dikonfirmasi. Penjual dapat melihat dan memodifikasi rincian yang menyangkut status pesanan, produk yang dipesan, pengiriman dan metode pembayaran, data pelanggan dan alamat.

7) Manajemen Diskon

Manajemen diskon memungkinkan penjual untuk mengatur diskon yang dapat diterapkan untuk produk tertentu atau untuk kategori produk tertentu.

8) Manajemen Pengiriman dan Pembayaran

Pada akhir proses, pengiriman dan komponen manajemen pembayaran mengatur semua data yang terkait dengan metode pengiriman dan pembayaran. Penjual dapat mengatur jenis pengiriman dan harga yang dapat bervariasi sesuai dengan negara tujuan order, berat, harga atau ukuran.

c. Komponen Hubungan sosial

1) Majemen daftar sosial

Tujuan komponen ini adalah untuk mengatur semua kegiatan pelanggan dan penjual yang berhubungan dengan daftar keinginan dalam konteks sosial.

2) Sistem Rekomendasi

Sistem rekomendasi manajemen terdiri oleh dua kegiatan: pengumpulan data dan data ekstraksi. Tujuan dari kegiatan pertama adalah untuk mengumpulkan hubungan antara pelanggan dan pelanggan, dan antara pelanggan dan barang. Selanjutnya, penjual dapat memutuskan tingkat prioritas pada produk untuk menghasilkan rekomendasi. Kemudian, selama fase ekstraksi data, komponen ini memilih beberapa item dalam rangka untuk memenuhi selera pelanggan dan menyarankan mereka untuk membeli produk ini.

3) Review Produk

Komponen manajemen review produk, tujuannya adalah untuk memungkinkan pelanggan untuk menulis ulasan berdasarkan skala 5-bintang dan yang berhubungan dengan produk tertentu.

4) Manajemen Rating

Komponen Peringkat transaksi memungkinkan pelanggan untuk menghasilkan ulasan dan suara tentang transaksi belanja. Dengan cara ini, pelanggan dapat mengekspresikan pandangan pribadi mereka tentang keandalan penjual, kecepatan pengiriman, keamanan pembayaran dan kualitas produk. ulasan pelanggan berguna untuk mendorong pembeli lain untuk membeli pada platform social commerce. 
5) Manajemen Komunikasi

Komponen terakhir adalah komunikasi. Tujuan dari komponen ini adalah memfasilitasi pertukaran informasi antara pelanggan dan penjual selama kegiatan pembelian online, sehingga mirip dengan) belanja perjalanan ke toko offline atau pusat perbelanjaan.

d. Komponen lain

1) Login

Komponen login memungkinkan pengguna untuk otentikasi ke dalam sistem memasukkan username dan password mereka sendiri. Setelah otentikasi berhasil, mereka dapat mengakses sebagai "pelanggan" atau "penjual".

2) Monitoring

Komponen monitoring, itu merupakan komponen utama dari infrastruktur yang terkait dengan pemangku kepentingan penjual. Hal ini memungkinkan penjual untuk memantau preferensi pelanggan dan kebutuhan.

\subsection{Perancangan}

Pada perancangan ini akan ditampilkan use case diagram dan activity diagram sebagai inti dari perancangan. Use diagram, telihat pada gambar 3. Pengunjung dapat melihat produk dan mendaftar akun pengguna. Pembeli dapat memesan produk, melakukan pembayaran, mereview produk, mengisi diskusi produk, mengelelola akun. Pemilik toko dapat mengelola toko, mengelola produk, mengelola akun toko, menerima pembayaran, mengirim produk. Sedangkan Administrator dapat mengelola toko, mengelola produk, mengelola seluruh akun yang terlibat dalam web.

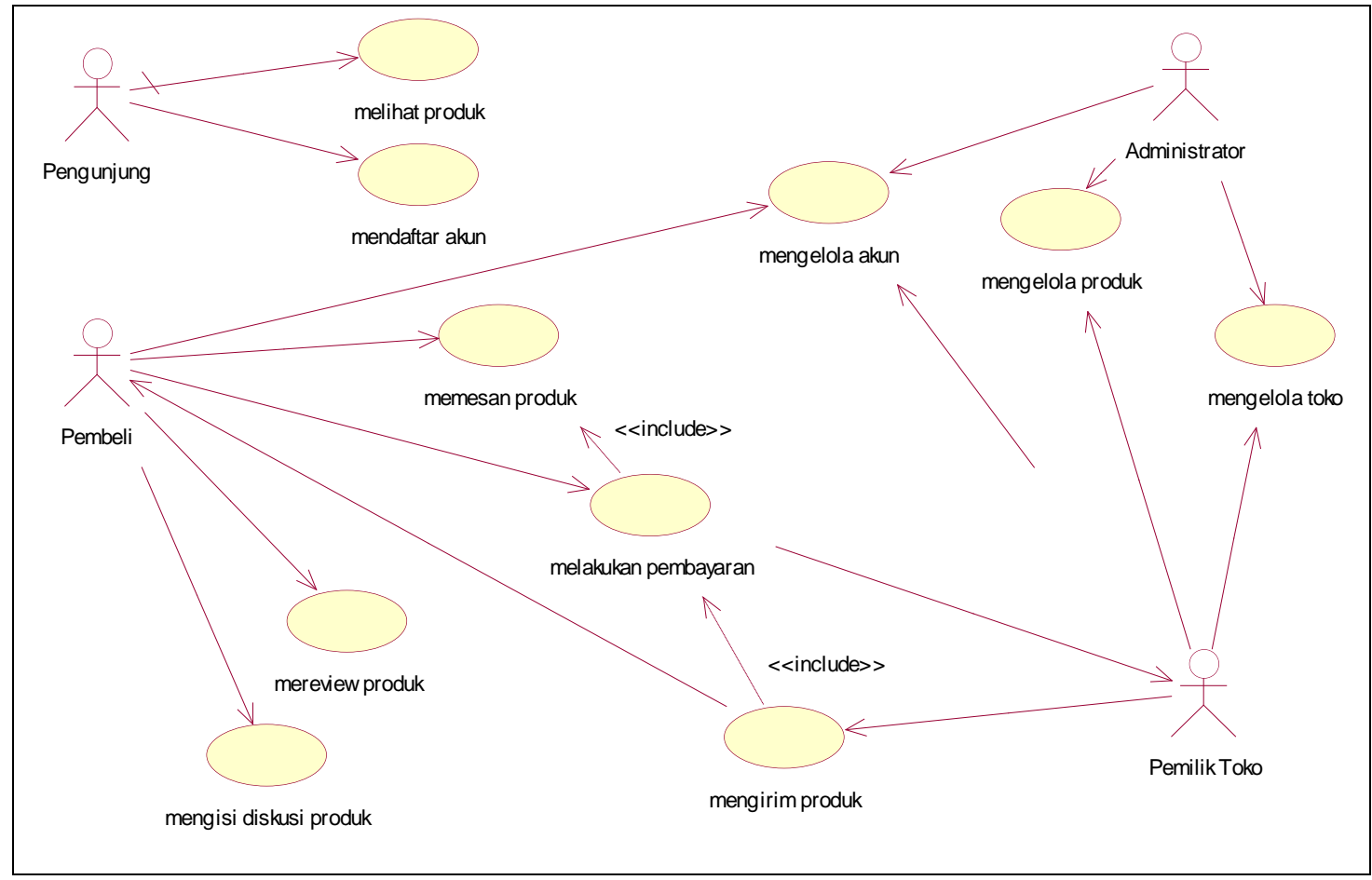

Gambar 3. Use Case Diagram social commerce

Pada gambar 4 menjelaskan, untuk aktivitas yang melibatkan sosial meliputi kegiatan lihat rating transaksi, lihat produk yang disarankan, lihat relihat produk, menambah daftar keinginan, menulis review produk, view daftar keinginan, hapus daftar produk yang diinginkan, masukkan barang ke kranjang belanja, masukkan rating transaksi. Selain itu merupakan kegiatan operasi bisnis biasa. 


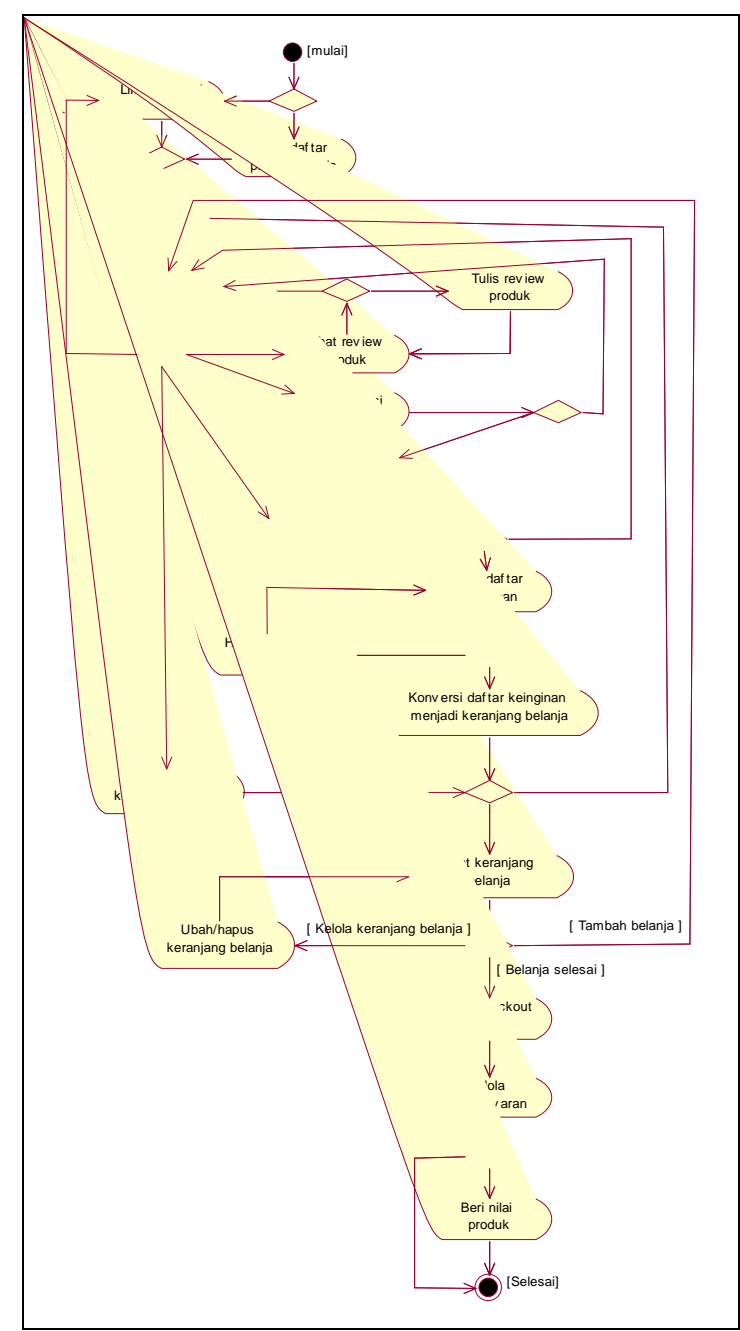

Gambar 4. Activity Diagram social commerce

\section{KESIMPULAN}

Pada makalah ini telah berhasil dilakukan analisa dan perancangan untuk social commerce UMKM yang meliputi diagram use case dan diagram activity.

\section{UCAPAN TERIMA KASIH}

Penelitian ini didanai oleh DP2M DIKTI (Direktorat Penelitian dan Pengabdian Kepada Masyarakat, Direktorat Jenderal Pendidikan Tinggi) melalui Program Desentralisasi Penelitian Hibah Bersaing Tahun 2016. Penulis mengucapkan terima kasih kepada DIKTI, Kopertis Wilayah VI dan Universitas Muria Kudus.

\section{ACUAN REFERENSI}

[1] Dennison, G., Bourdage-Braun, S., \& Chetuparambil, M. (2011). Social Commerce Defined

[2] Luca Salvatori dan Fausto Marcantoni (2015), " SmartSocialMarket: A Social Commerce Architecture", WEB 2015 : The Third International Conference on Building and Exploring Web Based Environments, ISBN: 978-1-61208-407-7

[3] Youcef Baghdadi (2013), "From E-commerce to Social Commerce: A Framework to Guide Enabling Cloud Computing ", J. theor. appl. electron. commer. res. vol.8 no. 3 Talca dic. 2013

[4] Endang Supriyati dan Mohammad Iqbal (2013), " Faktor Adopsi Internet Marketing Untuk Usaha Mikro Dan Usaha Kecil Menengah (Umkm) Di Kabupaten Kudus Dengan Sem (Structural Equation Model) Dan Framework Cobit 4.1”, Jurnal SIMETRIS, Vol 3 No 1 April 2013, ISSN: 2252-4983

[5] R. van Buuren, J. Gordijn and W. Janssen, "Business case modelling for e-services", in Proceedings 18th Bled E-Conference E-Integration in Action, Bled, 2005, pp. 8 